GRASAS Y ACEITES 72 (4)

October-December 2021, e434

ISSN-L: 0017-3495

https://doi.org/10.3989/gya.1000202

\title{
Enzymatic pre-treatment of grape seeds for an oil with higher antioxidant activity
}

\author{
๑M. Tociu ${ }^{\mathrm{a}}$, $₫$ A. Hirtopeanu ${ }^{\mathrm{b}}$ and $\odot$ M.D. Stanescu $\mathrm{u}^{\mathrm{a}, \mathrm{c}, \bowtie}$ \\ aPolitehnica University of Bucharest, Faculty of Applied Chemistry and Material Science, Organic Chemistry "Costin D. Nenitzescu" \\ Department, 1-7 Gheorghe Polizu Str., 011061, Bucharest, Romania. \\ b"Costin D. Nenitzescu" Centre of Organic Chemistry of the Romanian Academy, \\ 202 B Splaiul Independentei, 060021, Bucharest, Romania. \\ 'Aurel Vlaicu University of Arad, Faculty of Food Engineering, Tourism and Environmental Protection, 77 Revolutiei Blvd., 310032, \\ Arad, Romania \\ ${ }^{\circledR}$ Corresponding author: michaela.stanescu@chimie.upb.ro; stanescu@uav.ro
}

Submitted: 16 September 2020; Accepted: 06 November 2020; Published online: 02 January 2022

SUMMARY: The paper investigates the effect of the enzymatic pre-treatment of grape seeds from six Romanian cultivars on the oil extracted. The grape seeds of some white and red Romanian grape varieties were separated from winery waste, washed, dried and ground, with the oil then obtained by extraction with petroleum ether. The extraction was performed directly or after a preliminary treatment with a commercial pectin lyase. The enzymatic procedure applied was more cost effective compared to other treatments previously described in which a cocktail of enzymes was used. The quantity of the extracted oil was measured in both types of processing, with an increase being observed for pre-treated samples. The fatty acid profiles (FAPs) of the oils resulted for the treated and untreated seeds were determined. No change in the composition was noticed. The reductive power of these oils was also investigated. Compared to the untreated samples for the same variety, the enzyme pre-treatment resulted in a superior antioxidant capacity.

KEYWORDS: Antioxidants content; Fatty acid profile; Grape seeds; Pectin lyase treatment; Statistical analysis

RESUMEN: Pretratamiento enzimático de semillas de uva para un aceite con alta actividad antioxidante. En este artículo se investigó el efecto del tratamiento enzimático de semillas de uva de algunos cultivares rumanos sobre el aceite extraído. Las semillas de uva de variedades seleccionadas de uva rumana blanca y roja se separaron de los residuos de la bodega, se lavaron, secaron y molieron, a continuación el aceite se obtuvo mediante extracción con éter de petróleo. La extracción se realizó directamente o después de un tratamiento preliminar con una liasa de pectina comercial. El procedimiento enzimático aplicado es más rentable en comparación con otros tratamientos descritos anteriormente en los que se utilizó un cóctel de enzimas. La cantidad de aceite extraído se midió en ambos tipos de procesamiento y se observó un aumento para las muestras pretratadas. Se determinaron los perfiles de ácidos grasos (PAG) de los aceites resultantes de las semillas tratadas y no tratadas. No se notó ningún cambio en la composición. También se investigó el poder reductor de estos aceites. En comparación con las muestras no tratadas para la misma variedad, el pre-tratamiento enzimático dio lugar a una capacidad antioxidante superior.

PALABRAS CLAVE: Análisis estadístico; Contenido antioxidante; Pectina liasa tratamiento; Perfiles de ácidos grasos

Citation/Cómo citar este artículo: Tociu M, Hirtopeanu A, Stanescu MD. 2021. Enzymatic pre-treatment of grape seeds for an oil with higher antioxidant activity. Grasas Aceites 72 (4), e434. https://doi.org/10.3989/gya.1000202

Copyright: (C2021 CSIC. This is an open-access article distributed under the terms of the Creative Commons Attribution 4.0 International (CC BY 4.0) License. 


\section{INTRODUCTION}

The evaluation of any economic activity may be performed based on the economic value added (EVA) model developed in 1982 by G.B. Stewart, which is still used successfully (Stewart, 2013). In such context the valorization of the biomass waste from the industrial production of wine is important, as obtaining added value is a priority for any sustainable economy.

Romania is a known wine producer, being the $11^{\text {th }}$ producer in the world and the $5^{\text {th }}$ in Europe (European Commission, 2019). A sustainable development for winery implies the adequate management of resources in the production chain and reduction of waste (Maicas and Mateo, 2020). Waste minimization through technological innovation will generate an EVA equity indicator (Machová and Vrbka, 2018). A waste reduction policy is recommended for achieving a sustainable wine making process (Devesa-Rey et al., 2011) and the implementation of the "zero waste" concept (Donner et al., 2020).

Winery wastes are an important part of wine production. Grape pomace is a waste which results as a by-product from the must production; it is composed of around $30 \%$ stems, $30 \%$ seeds and $40 \%$ skins and pulp. It is considered an agro-industrial waste, representing about $25 \%(\mathrm{w} / \mathrm{w})$ of the weight of grapes processed and more than 9 million tons annually (Sirohia et al., 2020, Cvejic Hogervorst et al., 2017).

There are several proposals for solving the problem of pomace. It can be used in different applications such as functional foods and supplements, pharmaceutical and cosmetic products (Galanakis, 2020). The dispersal of it into landfill seems ecologically inappropriate (Dwyer et al., 2014). Viable solutions for winery waste valorization are: oil production (AlJuhaimi and Ozcan, 2018), manufacture of composite materials (Barbieri et al., 2013), extraction of the antioxidants for food supplements (Nowshehri et al., 2015), bioconversion to valuable chemicals or biofuels (Rani et al., 2020; Zacharof, 2017).

A better biomass valorization implies the separation of the pomace components (Toscano et al., 2013). The seeds represent a great part of these wastes, approximately $47 \%$ on dry base (Zhang et al., 2017), making their valorization vital.

The paper investigates the valorization of grape seeds by oil extraction. Residual grape seeds from six Romanian cultivars were processed. In order to increase the outcome, a pre-treatment of the seeds with a commercial pectin lyase was experimented. The enzymatic treatment seems appropriate due to the progress in the industrial production of enzymes as well as their numerous industrial applications derived from their properties, namely: low toxicity, energy saving due to mild work conditions, biodegradability, etc. (Choi et al., 2015). An improvement in oil quantity and/or quality was predicted.

\section{MATERIALS AND METHODS}

\subsection{Materials}

\subsubsection{Sample preparation}

The grape seeds were isolated from the pomace resulting from the wine making process, washed, dried for 24 hours (h) at room temperature, and ground. Seeds from the grape varieties of the 2015 harvest were investigated, namely four red brands, including Cabernet Sauvignon, Feteasca Neagra, Merlot, Pinot Noir and two white brands Columna and Riesling Italian. The material was supplied by the winery of Murfatlar, situated in Dobrogea, a south-eastern region of Romania.

\subsubsection{Commercial enzyme}

The pectin lyase solution (Pectinex XXL, activity $10.000 \mathrm{U} \mathrm{mL}^{-1}$ according to the supplier) was purchased from Novozymes A/S (Bagsvaerd, Denmark).

\subsubsection{Chemicals}

The $10-14 \% \mathrm{BF}_{3}$ solution in methanol was supplied by Merck (Darmstadt, Germany). Petroleum ether (b.p. $40-60{ }^{\circ} \mathrm{C}$ ), analytical grade methylene chloride, methanol, and 96\% ethanol solvents were purchased from Sigma Aldrich and were used as delivered. The citric acid and disodium phosphate dihydrate for the buffer solution were supplied by Sigma Aldrich.

\subsection{Equipment and procedures}

UV-Vis spectra (200-800 nm) were acquired on a Helios Beta apparatus with Vision software (Thermo Electron Corporation, Waltham, MA, United States).

The ${ }^{1} \mathrm{H}-\mathrm{NMR}$ spectra were obtained on a Bruker Avance III $400 \mathrm{MHz}$ spectrometer (Bruker BioSpin $\mathrm{GmbH}$, Rheinstetten, Germany). 
The GC analyses were performed on an Agilent Technologies 7890A instrument (2850 Centerville Road Wilmington, DE 19808-1610 USA), provided with a flame ionization detector.

\subsubsection{Enzymatic treatment}

Portions of $10 \mathrm{~g}$ ground grape seeds were kept for certain amounts of time in a solution of $3 \mathrm{~mL}$ commercial enzyme and $37 \mathrm{~mL}$ buffer solution of $\mathrm{pH}$ $3.5\left(0.1 \mathrm{M}\right.$ citric acid and $0.2 \mathrm{M} \mathrm{Na}_{2} \mathrm{HPO}_{4}, 2.3 / 1$ volume ratio), in $100 \mathrm{~mL}$ capped glass amber flasks, at room temperature $\left(20^{\circ} \mathrm{C}\right)$, with gentle intermittent stirring. The optimal time for treatment was established based on the oil yield (see Figure 1). For each grape seed variety the experiments were conducted in triplicate. After treatment, the seeds were separated by filtration, washed and dried before extraction.

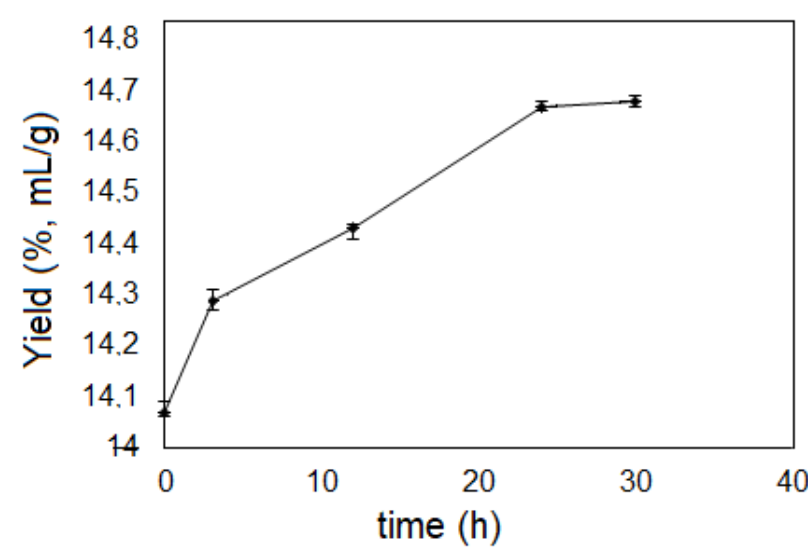

FIGURE 1. Variation in the extracted oil ( $\mathrm{mL}$ oil/100 $\mathrm{g}$ seeds) with the pre-treatment time for the Pinot Noir variety (Standard deviation for $\mathrm{n}=3$ )

The residual solution was concentrated in a Heidolph rotary evaporator, in a water bath $\left(50^{\circ} \mathrm{C}\right)$, and the residue was studied by NMR spectroscopy.

For checking the buffer effect on the grape seed a number of experiments were performed by keeping the seeds in the buffer solution (ratio $\mathrm{w} / \mathrm{v}=1 / 4$ ) for 24 hours, at room temperature. The quantity of the oil from these samples was in the same range as the corresponding untreated oil.

\subsubsection{Oil extraction}

The oil samples were obtained from the dried ground seeds (pre-treated or not with enzyme) by the Soxhlet extraction method with petroleum ether (b.p. $40-60{ }^{\circ} \mathrm{C}$ ), following the protocol ISO 659 (2009). The solvent was partially recovered by evaporation under atmospheric pressure, heated on a water bath at $65{ }^{\circ} \mathrm{C}$, using a Heidolph rotary evaporator. The weight of the oil was measured with an analytical balance (accuracy of $\pm 0.0001 \mathrm{~g}$ ) and the corresponding volume was calculated using the density value for grape seed oil of $0.92 \mathrm{~g} / \mathrm{mL}$ (Ceriani et al., 2008). The value of the density was confirmed by checking on a number of experimental samples. The experiments were performed in triplicate, the average volumes of oil being presented in Figure 2. The initial quantity of seeds was the same for both types of experiments (with or without pre-treatment) as measured before pre-treatment.

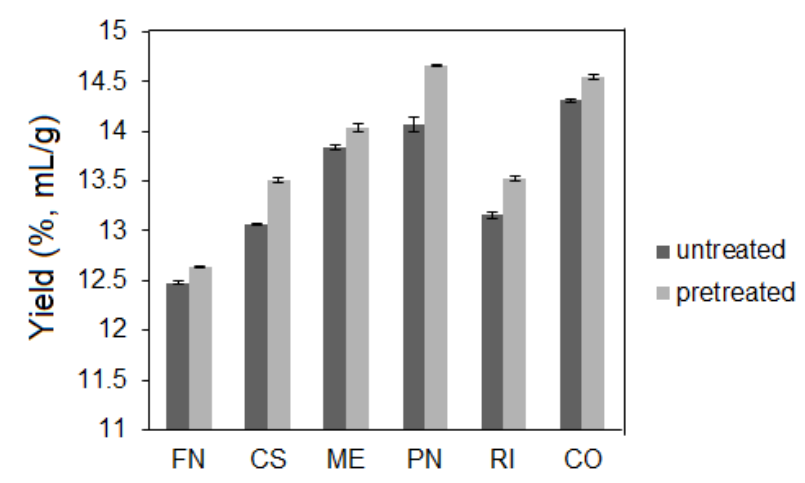

FIGURE 2. The oil amount (mL/100 g seeds) obtained by extraction from untreated and enzyme pre-treated seeds. (Standard deviation for $\mathrm{n}=3$; FN - Feteasca Neagra, CS - Cabernet Sauvignon, ME Merlot, PN - Pinot Noir, RI - Riesling Italian, CO - Columna)

\subsubsection{GC analysis of the grape seed oil composition (FAP)}

The grape seed oil FAPs were determined following the ISO 12966 (2015) protocol. The free fatty acids were obtained by treatment of $0.5 \mathrm{mg}$ oil with 0.9 $\mathrm{mL} \mathrm{NaOH} \mathrm{0.5} \mathrm{M} \mathrm{solution} \mathrm{in} \mathrm{methanol,} \mathrm{at} \mathrm{reflux,} \mathrm{for}$ $10 \mathrm{~min}$. Then, they were esterified by treatment with $0.1 \mathrm{~mL} \mathrm{BF}_{3}$ solution and $0.8 \mathrm{~mL}$ methanol, at reflux, for another $10 \mathrm{~min}$. After dilution with $4 \mathrm{~mL}$ distilled water, the fatty acid methyl esters (FAMEs) were extracted with methylene chloride and were submitted to a standard gas chromatographic (GC) analysis. GC analysis was performed on a highly polar capillary column Supelco SP $2560(100 \mathrm{~m} \times 0.25 \mathrm{~mm}, 0.20$ $\mu \mathrm{m}$ film) with a biscyanopropyl stationary phase. A certified reference material (Supelco ${ }^{\mathrm{TM}} 37$ Component FAME Mix) was used for the identification of the FAPs 
(see table 1). For each oil sample, three GC analyses were performed. The composition was expressed as a percentage based on the ratio between each peak area and the total area.

\subsubsection{Determination of the reductive power of the oil samples}

The CUPRAC assay (Apak et al., 2008) was applied to assess the total antioxidative capacity (TAC) of the oil. Samples of oil extracted by sonication in ethanol $(1 / 10, \mathrm{v} / \mathrm{v})$ were treated with $1 \mathrm{~mL} \mathrm{CuSO}_{4} 10^{-2} \mathrm{M}$ aqueous solution, $1 \mathrm{~mL}$ of 7.5 $\times 10^{-3} \mathrm{M}$ Neocuproine ethanolic solution, $1 \mathrm{~mL}$ $\mathrm{CH}_{3} \mathrm{COONH}_{4}$ buffer $(\mathrm{pH} 7)$ and $0.4 \mathrm{~mL}$ distilled water. After stirring for $30 \mathrm{~min}$, at room temperature, the absorbance (Abs) at $450 \mathrm{~nm}$ was measured. TAC was expressed as a trolox equivalent (TE, $\mu \mathrm{mol}$ per $100 \mathrm{~g}$ oil) based on a previously drawn calibration curve $\left(\mathrm{y}=0.058 \mathrm{x} ; \mathrm{R}^{2}=0.99\right)$. The average values obtained from three experiments for each oil sample are presented in Table 1.

\subsubsection{Determination of the total polyphenol content (TPPC) of the grape seeds}

The polyphenols (PPs) were quantified using the known Folin-Ciocalteu (FC) method (Ballus et al., 2015). Dried seeds ( $2 \mathrm{~g}$ ), before and after the oil extraction, were extracted with $9 \mathrm{~mL}$ ethanol/water
$(2 / 1, \mathrm{v} / \mathrm{v})$. Extract samples $(0.1 \mathrm{~mL})$ were mixed with the FC reagent $(0.5 \mathrm{~mL})$, distilled water $(1.5$ $\mathrm{mL}$ ) and, after $5 \mathrm{~min}$, with $20 \% \mathrm{Na}_{2} \mathrm{CO}_{3}$ solution $(1.5 \mathrm{~mL})$. The mixture was incubated for $2 \mathrm{~h}$, at room temperature, in the dark. The Abs at $750 \mathrm{~nm}$ was measured vs. a blank. The analyses were performed in triplicate, for seeds with or without enzymatic pretreatment, before and after oil extraction. The TPPC was expressed as gallic acid equivalents (GAE, mg per $100 \mathrm{~g}$ dried seeds) derived from a previously obtained calibration curve $\left(\mathrm{y}=0.061 \mathrm{x} ; \mathrm{R}^{2}=0.98\right)$ (Table 2).

\subsection{Statistical analysis}

To identify sample clusters the principal component analysis (PCA) was applied to the grape seed oil compositions. The independent variables were selected by PCA. The ANOVA program was used for the comparison of the mean values. Data analysis was performed using the XLSTAT 2015 software (Addinsoft).

\section{RESULTS AND DISCUSSION}

\subsection{Effects of the pre-treatment with pectin lyase on the grape seed oil yields}

The research was focused on the valorization of grape seeds from the waste of a Romanian winery

TABLE 1. FAPs and antioxidant content in the extracted grape seed oil

\begin{tabular}{|c|c|c|c|c|c|c|c|c|c|c|c|c|}
\hline Cultivar & FN & FNE & CS & CSE & ME & MEE & PN & PNE & RI & RIE & $\mathrm{CO}$ & COE \\
\hline Fatty acid & \multicolumn{12}{|c|}{ FA Content $(\%)$} \\
\hline $\begin{array}{l}\text { Palmitic and } \\
\text { Stearic }\end{array}$ & $10.58 \pm 0.02$ & $10.71 \pm 0.01$ & $11.11 \pm 0.02$ & $11.29 \pm 0.01$ & $9.02 \pm 0.02$ & $9.55 \pm 0.03$ & $10.34 \pm 0.01$ & $10.42 \pm 0.01$ & $9.88 \pm 0.02$ & $9.99 \pm 0.03$ & $8.78 \pm 0.01$ & $8.83 \pm 0.02$ \\
\hline $\begin{array}{c}\text { Oleic } \\
(18: 1 \text { cis-9) }\end{array}$ & $15.47 \pm 0.01$ & $15.84 \pm 0.03$ & $12.14 \pm 0.02$ & $12.36 \pm 0.03$ & $12.18 \pm 0.02$ & $12.62 \pm 0.02$ & $14.39 \pm 0.01$ & $14.53 \pm 0.03$ & $18.10 \pm 0.01$ & $18.18 \pm 0.01$ & $17.85 \pm 0.01$ & $17.90 \pm 0.01$ \\
\hline $\begin{array}{c}\text { Linoleic } \\
(18: 2 \text { cis,cis-9,12) }\end{array}$ & $73.76 \pm 0.02$ & $73.28 \pm 0.01$ & $76.48 \pm 0.02$ & $76.12 \pm 0.01$ & $78.34 \pm 0.01$ & $77.60 \pm 0.01$ & $75.05 \pm 0.02$ & $74.76 \pm 0.01$ & $71.79 \pm 0.02$ & $71.54 \pm 0.03$ & $73.13 \pm 0.01$ & $73.00 \pm 0.02$ \\
\hline $\begin{array}{c}\text { Linolenic } \\
(18: 3 \text { cis,cis,cis } \\
9,12,15)\end{array}$ & $0.19 \pm 0.01$ & $0.22 \pm 0.01$ & $0.27 \pm 0.01$ & $0.22 \pm 0.02$ & $0.28 \pm 0.02$ & $0.24 \pm 0.01$ & $0.23 \pm 0.01$ & $0.27 \pm 0.01$ & $0.23 \pm 0.01$ & $0.28 \pm 0.01$ & $0.24 \pm 0.01$ & $0.27 \pm 0.01$ \\
\hline $\begin{array}{c}\text { TAC } \\
(\mu \mathrm{mol} \\
\mathrm{TE} / 100 \mathrm{~g} \text { oil })\end{array}$ & $72.84 \pm 1.14$ & $176.75 \pm 1.31$ & $62.43 \pm 1.49$ & $131.64 \pm 1.45$ & $109.26 \pm 1.32$ & $216.18 \pm 1.19$ & $134.19 \pm 1.28$ & $234.48 \pm 1.54$ & $33.45 \pm 1.31$ & $58.73 \pm 1.40$ & $50.14 \pm 1.33$ & $85.12 \pm 1.49$ \\
\hline
\end{tabular}

Standard deviation for $\mathrm{n}=3$

FAPs - fatty acid profiles, FA - fatty acids, TAC - total antioxidative capacity, TE - trolox equivalent, FN - Feteasca Neagra, FNE - Feteasca Neagra pre-treated with enzyme, CS - Cabernet Sauvignon, CSE - Cabernet Sauvignon pre-treated with enzyme, ME -Merlot, MEE -Merlot pre-treated with enzyme, PN - Pinot Noir, PNE - Pinot Noir pre-treated with enzyme, CO - Columna, COE - Columna pre-treated with enzyme, RI - Riesling Italian, RIE - Riesling Italian pre-treated with enzyme. 
TABLE 2. Polyphenol content in grape seeds

\begin{tabular}{lcccccc}
\hline Sample Variety & PN & ME & FN & CS & CO & RI \\
\hline Analyzed sample & \multicolumn{5}{c}{ Polyphenols as GAE (mg/100 g seeds) } \\
\hline Initial & $132.27 \pm 1.33$ & $148.52 \pm 1.25$ & $133.74 \pm 1.33$ & $149.26 \pm 1.35$ & $133.74 \pm 1.39$ & $134.48 \pm 1.34$ \\
After extraction & $127.09 \pm 1.53$ & $128.57 \pm 1.34$ & $130.05 \pm 1.44$ & $144.09 \pm 1.59$ & $128.57 \pm 1.35$ & $127.09 \pm 1.33$ \\
After pre-treatment and extraction & $124.14 \pm 1.49$ & $125.62 \pm 1.43$ & $115.27 \pm 1.48$ & $135.22 \pm 1.54$ & $127.83 \pm 1.58$ & $124.14 \pm 1.34$ \\
\hline
\end{tabular}

Standard deviation for $\mathrm{n}=3$

GAE - gallic acid equivalents, PN - Pinot Noir, ME -Merlot, FN - Feteasca Neagra,

CS - Cabernet Sauvignon, CO - Columna, RI - Riesling Italian.

Murfatlar starting with the production of the grape oil. The oil obtained from grape seeds is a valuable material (Shinagawa et al., 2015). Recent clinical trials showed the beneficial effects of this oil on human health (Kaseb and Biregani 2016; Ismail et al., 2016).

The solvent extraction standardized method used for the oil separation is simple and less energy demanding than other procedures (Castro-Lopez et al., 2016). The yield is relatively high due to the permanent contact of ground seeds with clean solvent, which favors the extraction. The grinding of the seeds helps due to the generation of a larger contact area for seed-solvent. The solvent used, petroleum ether, is industrially accessible and not so toxic because of degrading rapidly in soil and water and having a halflife of 3-8 days in the air (Nalliah, 2014).

Vegetable oils may be produced also by cold pressing the seeds but the yield is usually lower and it is difficult to obtain a constant quality of the product (Ustun-Argon et al., 2020). The yield may be improved by using shockwaves but the process is complex and not always economically viable (Marousek, 2015a).

By comparison with other methods the solvent extraction of the grape seed oil has a low processing cost and is easy to handle (Galankis, 2020).

For improving the extraction process of bioactive compounds a number of procedures have been experimented, among which can be found supercritical fluid extraction, pressurized liquid extraction, microwave and ultrasound assisted extraction, etc. (Azmir et al., 2013; Kumar et al., 2017). Some of these procedures require investments which are suitable only for a large scale production.

Improvements of the extraction process may be done by pre-treatment of seeds before extraction. The literature has reported the following procedures: heating (Ustun-Argon et al., 2020), shockwave treatment (Marousek, 2015a), enzymatic hydrolysis
(Passos et al., 2009) or a combination of these methods (Marousek et al., 2015b).

According to the literature (González-Centeno et al., 2010), pectins are polymer constituents of the cell walls in fresh grapes or in grape pomace, which bind other constituents. The study of oil distribution inside the seed showed its presence near the external tegument (Pope et al., 1993). There is a relatively strong interaction between the oil and the seed walls leading to supramolecular structures (Scollary et al., 2012) which block oil removal. Thus, to improve oil extraction, an enzymatic pre-treatment was carried out, with an enzyme specific for pectin breaking. The enzymatic treatment (see paragraph 2.2.1) was performed in batch mode, by maintaining the seeds in a buffered solution of Pectinex XXL, at room temperature and $\mathrm{pH} 3.5$, parameters recommended for this type of enzymes (Najafian et al., 2009). The pectin lyase cleaves the pectin (Yadav et al., 2009) giving water soluble compounds (saturated and unsaturated pectic-oligosaccharides). The fragmentation process is improved by the presence of citric acid, which acts both as buffer and ligand for calcium ions (Stanescu et al., 2010). Thus, these ions, which reinforce the pectin structure by making bridge bonds between chains (Ochoa-Villarreal et al., 2012), are removed, aiding in the elimination of pectins. The fracture of the cell walls facilitates the access of solvent and improves the oil extraction yield. The chosen $\mathrm{pH}$ was the optimal one for the commercial enzyme used. Room temperature was suitable for the enzyme and did not require added cost for heating. The only parameter to be established was the treatment time. An optimal time of 24 hours was established for the enzymatic treatment based on the volume of the resulted oils for different time ranges (see Figure 1).

The enzymatic pre-treatment of seeds, for $24 \mathrm{~h}$ with Pectinex $X X L$, led to more oil, the quantities 
obtained being 101.3-104.3\% compared to untreated seeds (see Figure 2). Comparable results for the enzymatic pre-treatment of seeds have been found by other researchers (Passos et al., 2009). The performance of the described procedure consisted of lower additional costs than those with enzyme cocktails (Passos et al., 2009; Marousek et al., 2015). A preliminary calculation (Tociu, 2019a) indicated a reduced cost (of over 100 times) for the pre-treatment with only Pectinex XXL compared to the cost of the treatment with a mixture of cellulase, xylanase and pectinase performed by Passos et al., (2009), the differences in oil yield being insignificant.

Unfortunately, there are limitations to the application of enzymatic treatments such as the reproducibility of enzyme biosynthesis and the possible negative effects of the stabilizers on commercial products. These are impediments to the application of enzymatic treatments at large scale in processes where the enzyme properties (content, activity) are of great importance.

\subsection{Effects of pre-treatment with pectin lyase on the oil properties}

\subsubsection{FAPs of the grape seed oils}

One of the most important features of lipids is their fatty acid profile (FAP). The previous research involving enzymatic pre-treatment (Passos et al., 2009; Marousek et al., 2015b) did not check this aspect for the oil applications. Thus, the extracted oils were analyzed by a GC standard method (see paragraph 2.2.3). The FAPs of the oil samples are presented in Table 1.

The main component of these oils was linoleic acid, a representative polyunsaturated fatty acid (PUFA). The saturated fatty acid (SFA) content was around $10 \%$. Similar FAPs were revealed for Portuguese grape varieties (Fernandes et al., 2013) and Spanish wines with protected denomination of origin (Bada et al., 2015). Due to their low SFAs and high linoleic acid contents these oils present good nutritional qualities (Alsharari et al., 2017). According to the experimental results the pretreatment changed the FAPs only slightly $(\leq 0.4 \%)$.

As expected, the statistical analysis revealed a close correlation between PUFA and linoleic acid $(\mathrm{y}=$ $\left.1.004 x+0.1003 ; R^{2}=0.99\right)$. The grape variety showed an impact on the content in fatty acids in oil. Principal

\section{Biplot (axes F1 and F2: $86.05 \%$ )}

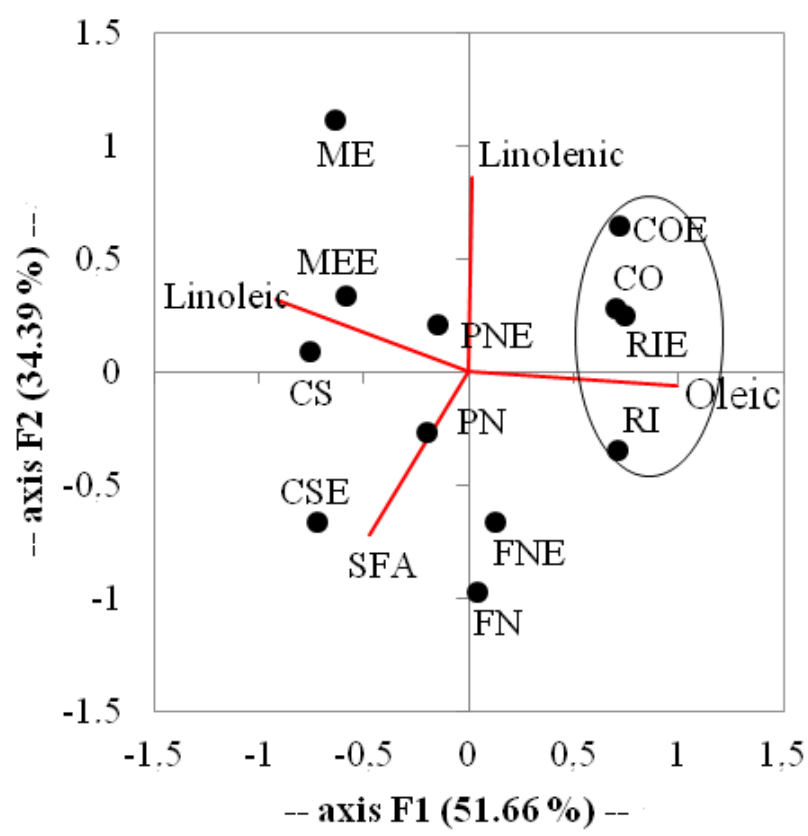

FiguRe 3. Principal component analysis based on FAPs. (CS - Cabernet Sauvignon, FN - Feteasca Neagra, ME -Merlot, PN Pinot Noir, CO - Columna, RI - Riesling Italian, CSE - Cabernet Sauvignon pre-treated with enzyme, FNE - Feteasca Neagra pretreated with enzyme, MEE -Merlot pre-treated with enzyme, PNE - Pinot Noir pre-treated with enzyme, COE - Columna pre-treated with enzyme, RIE - Riesling Italian pre-treated with enzyme, SFA saturated fatty acids)

component analysis (PCA) applied to FAPs disclosed the differences or similarities of the analyzed oils (Figure 3). The PCA analysis revealed the following eigenvalues: F1:2.067, F2: 1.375, F3: 0.558, F4: 0.000. Thus, the variance values of the principal components (PCs) were 51.66\% (F1), 34.39\% (F2), 13.95\% (F3) and $0.003 \%(\mathrm{~F} 4)$. The cumulative percentage for PC1 and PC2 coordinates was over $86.00 \%$ so only these 2 PCs had to be considered.

The oils from Columna and Riesling (with a higher content in oleic acid) as well as Merlot and Cabernet Sauvignon (with higher content in linoleic acid) showed a good discrimination on the F1 (PC1) direction; whereas Feteasca Neagra and Cabernet Sauvignon (with high content in SFA) exhibited good discrimination on the $\mathrm{F} 2$ ( $\mathrm{PC} 2)$ direction.

A comparison with oils from other seeds seemed of interest. According to the literature the average values for PUFAs (\%) (Chira et al., 2011) for oils obtained from sunflower $(59.77 \pm 4.80)$, soybean $(55.02 \pm 2.88)$ and rapeseed $(25.95 \pm 1.70)$ were by far lower than those for the grape seed oil $(75.00 \pm$ 
$2.40 \%)$. Thus, this oil stands out for its high content in healthy PUFAs.

\subsubsection{Total antioxidant capacity (TAC) of the grape seed oils}

Besides FAP, the antioxidant capacity of vegetable oils is essential for their applications (Chambre et al., 2019). The method used to establish the TAC was the CUPRAC assay. This assay is recommended due to its simplicity, reduced cost and reduced reaction time (Apak et al., 2008). It gives an accurate estimation of the TAC of the analyzed sample. The experimental results obtained for the studied oils are presented in Table 1. The oils obtained after the enzymatic treatments of seeds are richer in antioxidants, with the TAC values being 1.7-2.4 times higher compared to those of oils from untreated seeds (see Table 1). The enzymatic treatment destroyed not only the interactions of oil with the cell walls but also that of the antioxidants (Chamorro et al., 2012), increasing the quantities of extracted antioxidants. As expected, the oils obtained from the red grape varieties had higher antioxidant contents and improved health benefits.

A comparison of the TAC of grape seed oils (see Table 1) with other vegetable oil TACs is of interest. Thus, from the literature data the TAC values, expressed as TE (mmol kg-1) are as follows: 1.79 for extra virgin olive oil, 2.20 (soybean), 1.29 (corn), 1.17 (sunflower) (Pellegrini et al., 2003). Due to the enzymatic treatment the related grape seed oils are ranked in better positions by their TE values.

\subsection{Complementary possible valorization of other wastes}

The processing of grape seeds for oil extraction generates new wastes. Solutions have to be found for further valorization.

An investigation by ${ }^{1} \mathrm{H}-\mathrm{NMR}$ (see Figure $4 \mathrm{~b}$ ) of the residue resulting from the concentration of the solutions obtained after enzymatic treatment using a rotavap showed the presence of valuable products.

Occurrence of pectic-oligosaccharides was suggested by the gel aspect of the residue, as well as the specific ${ }^{1} \mathrm{H}-\mathrm{NMR}$ peaks at $4.2-4.5 \mathrm{ppm}$ and around the $5.1 \mathrm{ppm}$ (Winning et al., 2007). Other specific peaks are covered by the concentrated commercial enzyme signal (see Figure 4a) and the signal of the citric acid $(2.5-2.8 \mathrm{ppm})$ from

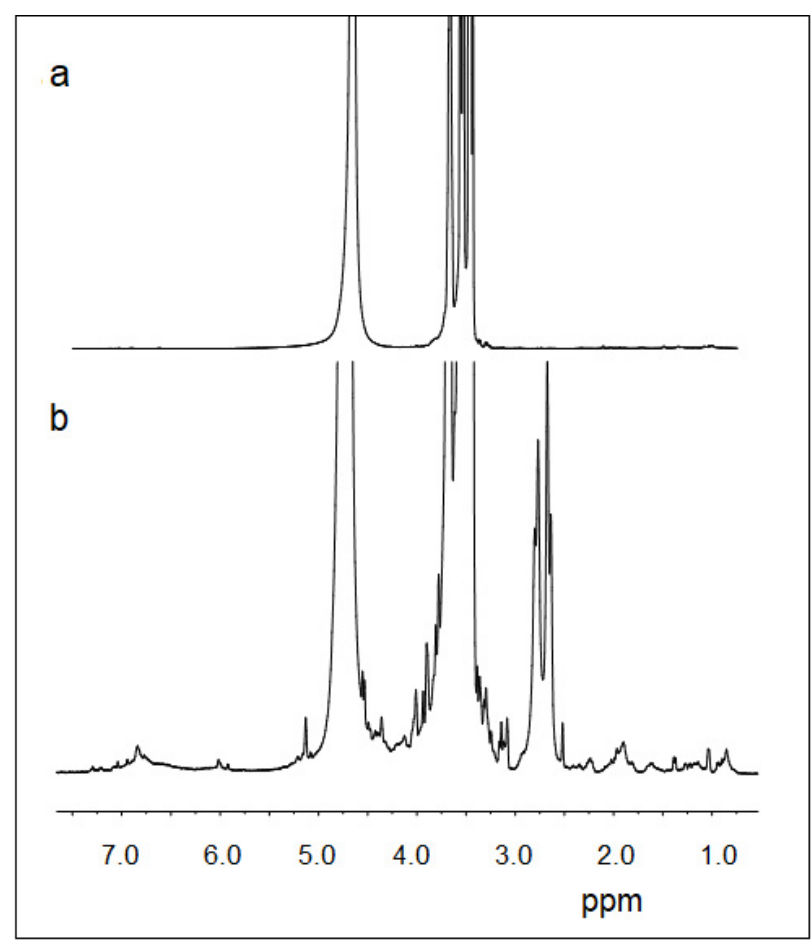

FiguRE 4. ${ }^{1} \mathrm{H}-\mathrm{NMR}$ spectra $\left(400 \mathrm{MHz}, \mathrm{D}_{2} \mathrm{O}\right.$, internal standard TSP) for (a) concentrated commercial enzyme; (b) residue obtained by concentrating the solution from the enzymatic pre-treatment

the buffer. Small peaks at 6.6-7.5 ppm evidenced the presence of aromatic compounds which were most likely traces of polyphenols (PPs) (Franz et al., 2014). There was no peak at $5.29 \mathrm{ppm}$ in the residue spectrum (Figure 4b), signal characteristic for $-\mathrm{CH}=\mathrm{CH}-$ of fatty acid (Chambre et al., 2019) as one may see in Figure 5, proving that no oil was lost during pre-treatment.

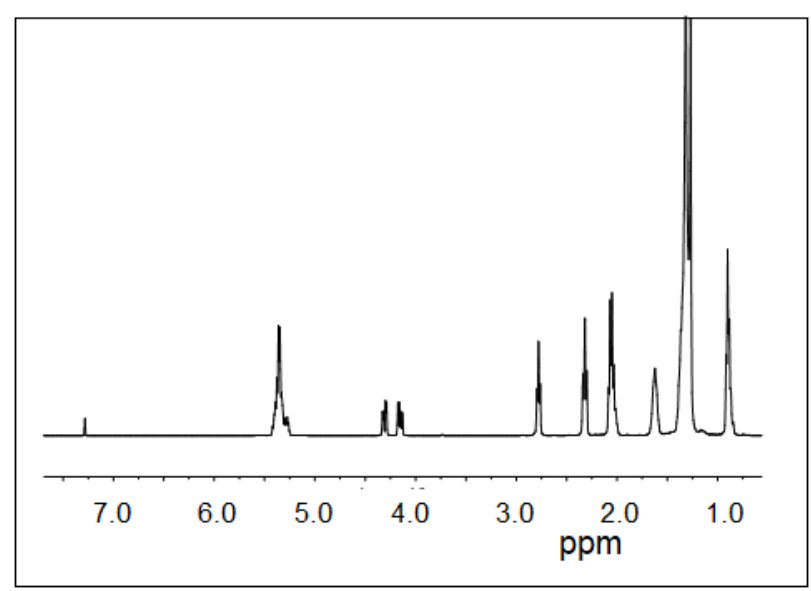

FiguRE 5. ${ }^{~} \mathrm{H}-\mathrm{NMR}$ spectrum $\left(400 \mathrm{MHz}, \mathrm{D}_{2} \mathrm{O}\right.$, internal standard TSP) of the oil extracted from the Cabernet Sauvignon seeds 
The residual grape seeds from the extraction of oil may be another source for PPs (Maier et al., 2009) as proven by the performed Folin-Ciocalteu assay presented in Table 2 .

After the extraction of the oil, the seeds hold over $86 \%$ of the initial quantity of PPs, most likely due to the reduced solubility of these compounds in petroleum ether. The literature data claim that vitamin $\mathrm{E}$ (tocopherols and tocotrienols) is the main antioxidant in grape seed oils (Wen et al., 2016). This fact was also confirmed by the thermal behavior of grape oils (Chambre et al., 2019).

Further investigation into the valorization of residual grape seed after extraction were also performed by isolating the PPs and using the lignocellulosic material for dye adsorption (Tociu, 2019a; Tociu et al., 2019b).

The economic impact of the enzymatic pretreatment has to be analyzed. Therefore, an accurate EVA analysis should be performed, considering all the by-products from the grape seeds (oil, PPs, adsorbents, char) not only the oil. Thus, new investigations must be carried out.

\section{CONCLUSIONS}

The paper presents the effect of a pectin lyase pre-treatment on grape seeds from six Romanian grape cultivars, raw materials for oil extraction. The following assertions resulted from the experimental work:

The effect of treatment on oil quantity is comparable to processes using cocktails of enzymes.

The statistical analysis indicates the influence of the seed origin on the FAP.

The enzymatic treatment does not affect the FAP of the extracted oils, which contain a high percentage of healthy unsaturated fatty acids.

The enzymatic pre-treatment increased significantly the antioxidant capacity of the extracted grape seed oils.

The antioxidant capacity of the oils is based mostly on vitamin E components as experimentally proven. Most of PPs remain in seeds.

The pre-treatment is performed in a batch system and in mild conditions not needing a complex production unit.

Further investigation into the residual solutions resulting from the enzymatic treatment to recover valuable products, e.g. oligopectins and PPs, are required.

\section{ACKNOWLEDGMENT}

The University of Bucharest is gratefully acknowledged for NMR access (UniRem project no. 244).

\section{REFERENCES}

Al-Juhaimi F, Ozcan MM. 2018. Effect of cold press and soxhlet extraction systems on fatty acid, tocopherol contents, and phenolic compounds of various grape seed oils. J. Food Process. Pres. 42 (1), e13417. https://doi.org/10.1111/jfpp.13417

Alsharari ZD, Riserus U, Leander K, Sjogren P, Carlsson AC, Vikstrom M, Laguzzi F, Gigante B, Cederholm T, De Faire U, Hellenius ML, Marklund M. 2017. Serum Fatty Acids, Desaturase Activities and Abdominal Obesity - A Population-Based Study of 60-Year Old Men and Women. PloS one 12 (1), 0170684. https://doi. org/10.1371/journal.pone.0170684

Apak R, Guclu K, Ozyurek M, Celik SE. 2008. Mechanism of antioxidant capacity assays and the CUPRAC (cupric ion reducing antioxidant capacity) assay. Microchim. Acta 160, 413-419. https://doi.org/10.1007/s00604-007-0777-0

Azmir J, Zaidul ISM, Rahman MM, Sharif KM, Mohamed A, Sahena F, Jahurul MHA, Ghafoor K. 2013. Techniques for extraction of bioactive compounds from plant materials: A review. J. Food Eng. 117, 426-436. https://doi. org/10.1016/j.jfoodeng.2013.01.014

Bada JC, León-Camacho M, Copovi P, Alonso L. 2015. Characterization of grape seed oil from wines with protected denomination of origin (PDO) from Spain. Grasas Aceites 66 (3), e085. https://doi.org/10.3989/gya.1063142

Ballus CA, Meinhart AD, de Souza Campos FA, Teixeira Godoy H. 2015. Total Phenolics of Virgin Olive Oils Highly Correlate with the Hydrogen Atom Transfer Mechanism of Antioxidant Capacity. J. Am. Oil. Chem. Soc. 92, 843-851. https://doi.org/10.1007/s11746-015-2629-0

Barbieri L, Andreola F, Lancellotti I, Taurino R. 2013. Management of agricultural biomass wastes: Preliminary study on characterization and valorisation in clay matrix bricks. Waste Manage. 33 (11), 2307-2315. https://doi.org/10.1016/j. wasman.2013.03.014

Castro-Lopez C, Rojas R, Sanchez-Alejo EJ, NinoMedina G, Martínez-Avila GCG. 2016. Phenolic 
Compounds Recovery from Grape Fruit and ByProducts: An Overview of Extraction Methods, in: Morata A and Loira I (Eds.) Grape and wine biotechnology, InTech, Rijeka, 103-123. https:// doi.org/10.5772/64821

Ceriani R, Paiva FR, Gonçalves CB, Batista EAC, Meirelles AJA. 2008. Densities and Viscosities of Vegetable Oils of Nutritional Value. J. Chem. Eng. 53 (8) 1846-1853. https://doi.org/10.1021/ je800177e

Chambre DR, Tociu M, Stanescu MD, Popescu C. 2019. Influence of composition on the thermal behavior of oils extracted from the seeds of some Romanian grapes. J. Sci. Food Agric. 99 (14), 6324-6332. https://doi.org/10.1002/jsfa.9909

Chamorro S, Viveros A, Alvarez I, Vega E, Brenes A. 2012. Changes in polyphenol and polysaccharide content of grape seed extract and grape pomace after enzymatic treatment. Food Chem. 133 (2), 308-314. https://doi.org/10.1016/j.foodchem.2012.01.031

Choi J-M, Han S-S, Kim H-S. 2015. Industrial applications of enzyme biocatalysis: Current status and future aspects. Biotechnol. Adv.33 (7) 1443-1454. https://doi.org/10.1016/j.biotechadv.2015.02.014

Cvejic Hogervorst J, Miljić U, Puškaš V. 2017. Extraction of Bioactive Compounds from Grape Processing By-Products, in Galanakis C (Ed.) Handbook of Grape Processing By-Products explores. Sustainable solutions. AcademicPress, Cambridge Massachusetts, 105-132. https://doi. org/10.1016/B978-0-12-809870-7.00005-3

Devesa-Rey R, Vecino X, Varela-Alende JL, Barral MT, Cruz JM, Moldes AB. 2011. Valorization of winery waste $v s$. the costs of not recycling. Waste Manage. 31 (11), 2327-2335. https://doi. org/10.1016/j.wasman.2011.06.001

Donner M, Gohier R, de Vries H. 2020. Anew circular business model typology for creating value from agrowaste. Sci. Total Environ. 716, 137065. https://doi.org/10.1016/j.scitotenv.2020.137065

Dwyer K, Hosseinian F, Rod M. 2014. The market potential of grape waste alternatives. J. Food Res. 3 (2), 91-106. https://doi.org/10.5539/jfr.v3n2p91

Fernandes L, Casal S, Cruz R, Pereira JA, Ramalhosa E. 2013. Seed oils of ten traditional Portuguese grape varieties with interesting chemical and antioxidant properties. Food Res. Int. 50 (1), 161-166. https://doi.org/10.1016/j. foodres.2012.09.039
Franz AH, Serebnitskaya I, Guidal G, Wallis C. 2014. Structure assignment and H/D-exchange behavior of several glycosylated polyphenols (14-8583QP). ARKIVOC V, 94-122. https://doi. org/10.3998/ark.5550190.p008.583

European Commission. 2019. Evaluation of the CAP measures applicable to the wine sector. Case study report, Publications Office of the European Union, Luxembourg. https:// ec.europa.eu/info/ sites/info/files/food-farming-fisheries/key_ policies/documents/case-study-wine-evaluationromania_en.pdf

Galanakis C. 2020. Life cycle assesment in food industry, in Galanakis C (Ed) The Interaction of Food Industry and Environment. Academic Press, Cambridge Massachusetts, 377-386. https://doi. org/10.1016/B978-0-12-816449-5.00011-4

Gonzalez-Centeno MR, Rossello C, Simal S, Garau MC, Lopez F, Femenia A. 2010. Physico-chemical properties of cell wall materials obtained from ten grape varieties and their byproducts: grape pomaces and stems. LWT - Food Sci. Technol. 43 (10), 1580-1586. https://doi.org/10.1016/j. lwt.2010.06.024

Ismail AF, Salem AA, Eassawy MM. 2016. Hepatoprotective effect of grape seed oil against carbon tetrachloride induced oxidative stress in liver of $\gamma$-irradiated rat. J. Photochem. Photobiol B: Biology 160, 1-10.

ISO 659, 2009. Oilseeds - Determination of oil content (Reference method).

ISO 12966, 2015. Animal and vegetable fats and oils - Gas chromatography of fatty acid methyl esters - Part 4: Determination by capillary gas chromatography.

Kaseb F, Biregani AN. 2016. Effects of Olive Oil and Grape Seed Oil on Lipid Profile and Blood Pressure in Patients with Hyperlipidemia: A Randomized Clinical Trial. Food Nutr. Sci. 7 (8), 682-688. https://doi.org/10.4236/fns.2016.78069

Chira N, Todasca MC, Nicolescu A, Rosu A, Nicolae M, Rosca SI. 2011. Evaluation of the Computational Methods for Determining Vegetable Oils Composition using 1H-NMR Spectroscopy. Rev. Chim., 26 (1) 42-46. https:// www.revistadechimie.ro/

Kumar K, Yadav AN, Kumar V, Vyas P, Dhaliwal HS. 2017. Food waste: a potential bioresource for extraction of nutraceuticals and bioactive 
compounds. Bioresour. Bioprocess. 4, 18. https:// doi.org/10.1186/s40643-017-0148-6

Machová V, Vrbka J. 2018. Value generators for businesses in agricultura, in Löster T, Pavelka $\mathrm{T}$ (Eds) International Days of Statistics and Economics Conference Proceedings. MELANDRIUM, Slany, Czech Republic, 11231132. https://msed.vse.cz/msed_2018/article/57Machova-Veronika-paper.pdf

Maicas S, Mateo JJ. 2020. Sustainability of Wine Production. Sustainability 12, 559 https:// doi:10.3390/su12020559

Maier T, Schieber A, Kammerer DR, Carle R. 2009. Residues of grape (Vitis vinifera L.) seed oil production as a valuable source of phenolic antioxidants. Food Chem. 112 (3), 551-559. https://doi.org/10.1016/j.foodchem.2008.06.005

Marousek J. 2015a. Economic Analysis of the Pressure Shockwave Disintegration Process. IJSGE 12 (12) 1232-1235. https://doi:10.1080/1 5435075.2014 .895740

Maroušek J, Hašková S, Maroušková A, Myšková K, Vaníčková R, Váchal J, Vochozka M, Zeman R, Žák J. 2015b. Financial and Biotechnological Assessment of New Oil Extraction Technology. Energy Sources, Part A: Recovery, Utilization, and Environmental Effects 37 (16) 1723-1728. https://doi:10.1080/15567036.2015.1048391

Najafian L, Ghodsvali A, Haddad Khodaparast MH, Diosady LL. 2009. Aqueous extraction of virgin olive oil using industrial enzymes. Food Res. Int. 42 (1), 171-175. https://doi.org/10.1016/j. foodres.2008.10.002

Nalliah RE. 2014. Petrolem ether, in Wexler Ph(Chief Ed.) Encyclopedia of Toxicology, 3rd edition, Academic Press, Cambridge Massachusetts, 834837. https://doi.org/10.1016/B978-0-12-3864543.00418-8

NovozymesA/S. 2012. ProductData SheetPectinex ${ }^{\circledR}$ XXL www.sinerji-as.com/files/0ec4f308-1c6141b6-a897-725d0aba8a52.pdf

Nowshehri JA, Bhat ZA, Shah MY. 2015. Blessings in disguise: Bio-functional benefits of grape seed extracts. Food Res. Int. 77 (3), 333-348. https:// doi.org/10.1016/j.foodres.2015.08.026

Ochoa-Villarreal M, Aispuro-Hernandez E, VargasArispuro I, Martínez-Tellez, MA. 2012. Plant Cell Wall Polymers: Function, Structure and Biological Activity of Their Derivatives, in De
Souza Gomes A (Ed.) Polymerization, InTech, Rijeka, pp. 63-84.

Passos CP, Yilmaz S, Silva CM, Coimbra MA. 2009. Enhancement of grape seed oil extraction using a cell wall degrading enzyme cocktail. Food Chem. 115 (1), 48-53. https://doi.org/10.1016/j. foodchem.2008.11.064

Pellegrini N, Serafini M, Colombi B, Del Rio D, Salvatore S, Bianchi M, Brighenti F. 2003. Total Antioxidant Capacity of Plant Foods, Beverages and Oils Consumed in Italy Assessed by Three Different In Vitro Assays. J. Nutr. 133 (9), 28122819. https://doi.org/10.1093/jn/133.9.2812

Pope JM, Jonas D, Walker RR. 1993. Applications of NMR micro-imaging to the study of water, lipid, and carbohydrate distribution in grape berries. Protoplasma 173, 177-186. https://doi. org/10.1007/BF01379006

Rani J, Yadav Indrajeet, Rautela A, Kumar S. 2020. Biovalorization of winery industry waste to produce value-added products, in Rathinam NK, Sani RK (Eds) Biovalorisation of Wastes to Renewable Chemicals and Biofuels, Elsevier, Amsterdam, 63-85. https://doi.org/10.1016/ B978-0-12-817951-2.00004-3

Scollary GR, Pasti G, Kallay M, Blackman J, Clark AC. 2012. Astringency response of red wines: Potential role of molecular assembly. Trends Food Sci. Technol. 27 (1), 25-36. https://doi. org/10.1016/j.tifs.2012.05.002

Shinagawa FB, de Santana FC, Torres LRO, ManciniFilho J. 2015. Grape seed oil: a potential functional food? Food Sci. Technol. (Campinas) 35, 399-406. https://doi.org/10.1590/1678-457X.6826

Sirohia R, Tarafdarb A, Singha S, Negic T, Kumar Gaurd V, Gnansounou, Bharathirajag B. 2020. Green processing and biotechnological potential of grape pomace: Current trends and opportunities for sustainable biorefinery. Bioresour. Technol. 314, 123771. https://doi.org/10.1016/j.biortech.2020. 123771

Stanescu MD, Dochia M, Radu D, Sirghie C. 2010. Green solution for cotton scouring. Fibres Text. East. Eur. 3 (80), 109-111. www.fibtex.lodz.pl Stewart BG. 2013. Best-Practice EVA. The Definitive Guide to Measuring and Maximizing Shareholder Value. John Wiley \& Sons, Inc., Hoboken.

Tociu M. 2019a. PhD Thesis, Study of natural fats from vegetable oils and milk: composition, factor 
of influence and authentication, Aspects of waste valorization, Bucharest

Tociu M, Oprea O, Stanescu MD. 2019b. Preliminary investigations for the valorization of grape seeds after the oil extraction. U.P.B. Sci. Bull., Series B 81 (2), 47-56. https://www. scientificbulletin.upb.ro/rev_docs_arhiva/ full828 896673.pdf

Toscano G, Riva G, Duca D, Foppa Pedretti E, Corinaldesi F, Rossini G. 2013. Analysis of the characteristics of the residues of the wine production chain finalized to their industrial and energy recovery. Biomass Bioenerg. 55, 260-267. https://doi.org/10.1016/j.biombioe.2013.02.015

Ustun Argon Z, Celenk VU, Gumus ZP. 2020. Cold pressed grape (Vitis vinifera) seed oil, in Ramadan MF (Ed.) Green Technology, Bioactive Compounds, Functionality, and Applications. Academic Press, Cambridge Massachusetts, 3952. https://doi.org/10.1016/B978-0-12-8181881.00005-0

Wen X, Zhu M, Hu R, Zhao J, Chen Z, Li J, Ni Y. 2016. Characterisation of seed oils from different grape cultivars grown in China. J. Food Sci. Technol. 53, 3129-3136. https://doi.org/10.1007/ s13197-016-2286-9

Winning $\mathrm{H}$, Viereck $\mathrm{N}$, Norgaard L, Larsen J, Engelsen SB. 2007. Quantification of the degree of blockiness in pectins using ${ }^{1} \mathrm{H}$ NMR spectroscopy and chemometrics. Food Hydrocoll. 21 (2), 256-266. https://doi.org/10.1016/j. foodhyd.2006.03.017

Yadav S, Yadav PK, Yadav D, Yadav KDS. 2009. Pectin lyase: A review. Process Biochem. 44 (1), 1-10. https://doi.org/10.1016/j. procbio.2008.09.012

Zacharof MP. 2017. Grape Winery Waste as Feedstock for Bioconversions: Applying the Biorefinery Concept. Waste Biomass Valor. 8, 1011-1025.

https://doi.org/10.1007/s12649-016-9674-2

Zhang N, Hoadley A, Patel J, Lim S, Li C. 2017. Sustainable options for the utilization of solid residues from wine production. Waste Manage. 60, 173-183. https://doi.org/10.1016/j. wasman.2017.01.006 